\title{
QUALITY PROPERTIES OF COOKIES SUPPLEMENTED WITH FRESH BREWER'S SPENT GRAIN
}

\author{
Jovana S. Petrović, ${ }^{* 1}$, Biljana S. Pajin, Sunčica D. Kocić Tanackov, Jelena D. Pejin, Aleksandar Z.
} Fišteš, Nemanja Đ. Bojanić, Ivana S. Lončarević

University of Novi Sad, Faculty of Technology, 21000 Novi Sad, Bulevar cara Lazara 1, Serbia

\author{
${ }^{*}$ Corresponding author: \\ Phone: +381-21-48-53-788 \\ Fax: +381-21-45-04-13 \\ E-mail address: jovana@tf.uns.ac.rs
}

\begin{abstract}
Brewer's spent grain (BSG) is a by-product generated during the brewing process. It is a rich source of dietary fibre and proteins, with great potential to increase nutritional value of food products. In this research different quantities of fresh (non-dried and non-milled) brewer's spent grain $(15,25$ and $50 \%)$ were added to wheat flour on a replacement basis in order to evaluate its effect on fibre and protein content, instrumental parameters of colour, microbial stability and sensory characteristics of cookies. Protein and fibre content of cookies increased following the addition of BSG from $7.55 \%$ to $9.69 \%$ and 6.8 to $15.55 \%$, respectively. Considering the colour characteristics, addition of BSG decreased $\mathrm{L}^{*}$ and $\mathrm{b}^{*}$ values, while $\mathrm{a}^{*}$ values increased. Enterobacteriaceae, Escherichia coli, Clostridium spp., yeasts and moulds were not detected in cookie samples, while the Enterobacteriaceae were detected (40 cfu/g) in fresh BSG. The addition of $25 \%$ of BSG resulted in best sensory characteristics of cookies in terms of surface appearance, hardness, grittiness and flavour. The results have shown that fresh BSG has a potential to increase nutritional value of the cookies without negative influence on cookie sensory characteristics and microbiological stability.
\end{abstract}

Key words: cookies, brewer's spent grain, colour, sensory properties, microbial profile

\section{INTRODUCTION}

The food and beverage industry produces large quantities of by-products (Stojceska et al., 2008). In recent years, the possibilities for food by-products recovery attracted increasing attention. Many of these waste or by-products contain significant amounts of valuable components and have a potential to be utilized as functional ingredients in order to increase the nutritional value of food products (Rodriguez et al., 2006; Ktenioudaki et al., 2013a, 2013b).

Brewer's spent grain (BSG) is the main by- product generated during the brewing process, available in large quantities throughout the year, and at low cost (Stojceska, 2011; Kitryte et al., 2015). Due to its high moisture content and fermentable sugar content, brewer's spent grain deteriorates very easily becoming an environmental problem after a short time (ElShafey et al., 2004). This is the reason why it is regarded as a problematic waste by the industry so any additional uses of BSG would be advantageous due to the increasing cost of their disposal (McCarthy 
et al., 2012). BSG is usually dried to overcome this problem. Dried BSG is considered as lignocellulosic material rich in hemicelluloses $(39 \%)$, proteins $(24 \%)$, cellulose (14\%), lipids (6\%), and lignin (4\%) (Mussatto et al., 2006). BSG is mainly used as a feedstuff, fertilizer, source of energy and recently as a source for the production of alpha-amylase, activated carbon, ethanol, lactic acid and xylitol (Mussatto et al., 2006, Meneses et al., 2013). Due to its relatively low cost and nutritional value, together with pressure on the food industry to minimize the environmental impact, BSG has a great potential to be used as a valuable food additive (Santos et al., 2003; Laufenberg et al., 2003; Mussatto et al., 2006; Stojceska et al., 2008). This especially applies to the incorporation of BSG into different cereal based and bakery products (breads, cookies, snacks, cakes, waffles, etc.) which has been demonstrated by numerous investigations (Mussatto et al., 2006; Finley and Hanamoto, 1980; Kawka et al., 1999; Prentice \& D'Appolonia, 1977; Kissell et al., 1979; Prentice et al., 1978; Stojceska and Ainsworth, 2008; Stojceska et al., 2008; Sudha et al., 2007; Ktenioudaki et al., 2012, 2013a).

Cookies are popular confectionery product made out of wheat flour. Since widely accepted and consumed, with relatively long shelf-life and ready-to-eat form, they represent a valuable supplementation vehicle for nutritional improvement (Arshad et al., 2007; Lorens et al., 1979). They are usually highly caloric, but low in protein and especially fibre content (Manley, 2011). BSG is particularly rich in protein and fibre content what makes it an ideal nutritional fortifier for cookies. However, any substitution of wheat flour with ingredients with higher fibre content results in the weakening of the gluten network. The main issue associated with the incorporation of BSG in food products is the effect on texture and flavour (Steinmacher et al., 2012; Ktenioudaki et al., 2013b). Considering cookies and biscuits, it has been reported that sensory attributes has been deteriorated following the addition of more than $15 \%$ of BSG (Kissell and Prentice, 1979).
BSG is usually prepared by grinding and sifting of dry BSG. Since drying can be considered as energy-consuming and expensive process, the primary objective of this study was to examine the effects of adding fresh (no-dried and no-milled) BSG on sensory and some nutritional properties of cookies. Since BSG was used in fresh form, the microbial stability of cookies was also examined.

\section{MATERIAL AND METHODS}

\section{Preparation of cookies}

Blends of wheat flour containing 15, 25 and $50 \%$ of fresh, non-milled BSG, on a replacement basis, were prepared using the F-6-RVC agitator (Forberg International AS, Norway). Control cookie sample was prepared using wheat flour without BSG. Cookie doughs were prepared according to Petrović et al. (2015): flour (i.e. flour blend) $200.00 \mathrm{~g}$, vegetable fat 42.00 $\mathrm{g}$, sugar $70.00 \mathrm{~g}$, sodium bicarbonate 0.6 $\mathrm{g}$, ammonium hydrogen carbonate $0.4 \mathrm{~g}$ and $\mathrm{NaCl} 1.1 \mathrm{~g}$. The amount of water was calculated in relation to the water content of the flour blends in order to obtain dough samples with $24 \%$ moisture content. Prepared cookie dough was baked for $10 \mathrm{~min}$ at $220{ }^{\circ} \mathrm{C}$ in a laboratory oven (Profil, Kragujevac, Serbia). Cookie sample with $15 \%$ BSG was marked as B15, with $25 \%$ BSG as B25 and with $50 \%$ BSG as B50, while control sample was prepared only with wheat flour.

\section{Determination of protein and fibre content}

Protein content of cookies was determined according to the Kjeldahl method described in the AOAC (2000). The factor $n=$ 6.25 for cookies were used for conversion of nitrogen to crude protein (Arshad et al., 2007). The total dietary fibre content was determined using a combination of enzymatic and gravimetric methods (SigmaAldrich Inc., St. Louis, MO, USA) (AOAC, 1997). Milled and defatted samples were gelatinized with heat stable $\alpha$-amylase and then enzymatically digested with protease and amyloglucosidase to remove protein and starch present in the sample. Ethanol was added to precipitate the soluble dietary fibre. The residue was then filtered 
and washed with ethanol and acetone. After drying, the residue was weighed. One duplicate was analysed for protein and the other was incubated at $525^{\circ} \mathrm{C}$ to determine ash. Total dietary fibre is the weight of the residue less the weight of the protein and ash.

\section{Microbiological analysis}

Microbiological analyses were performed on fresh BSG used for cookie preparation and on cookie samples in duplicate. Twenty grams of samples were homogenized for $10 \mathrm{~min}$ at $200 \mathrm{rpm}$ (Unimax 1010, Heidolph, Germany) in $180 \mathrm{~mL} 1 \mathrm{~g} / \mathrm{L}$ buffered peptone water (Merck, Darmstadt) and then sequence of decimal dilution were prepared (up to $10^{-3}$ ). One millilitre of each dilution was placed in a sterile Petri plate and poured with appropriate media depending on the type of tested microorganism. Total aerobic mesophilic bacteria count was enumerated in Plate Count Agar (PCA) (Merck, Darmstadt, Germany) and incubated at 30 ${ }^{\circ} \mathrm{C}$ for $72 \mathrm{~h}$; total yeasts and moulds count was enumerated in Dichloran Rose Bengal Chloramphenicol agar (DRBC) (Merck, Darmstadt, Germany) and incubated at 25 ${ }^{\circ} \mathrm{C}$ for 5 days; Escherichia coli was determined on Tryptone Bile Glucuronic Agar (TBX agar) (Merck, Darmstadt) after an incubation at $37{ }^{\circ} \mathrm{C}$ for 24-48 h; Clostridium spp. was determined on Tryptone Sulfite Cycloserine (TSC) Agar (Merck, Darmstadt) after an incubation under anaerobic conditions at $37^{\circ} \mathrm{C}$ for $24-48 \mathrm{~h}$; total Enterobacteriaceae count was enumerated in Violet Red Bile Glucose Agar (VRBGA) (Merck, Darmstadt, Germany) at $37^{\circ} \mathrm{C}$ for $24-48 \mathrm{~h}$. After incubation, typical and atypical grown colonies have been identified by microscopic observation of cell morphology and also with biochemical tests. Results were expressed as a number of colony forming units per gram (cfu/g).

\section{Cookie colour determination}

Cookie's upper surface colour was measured in triplicates, $24 \mathrm{~h}$ after baking. The CIELab colour coordinates ( $L^{*}$ - light-ness, $a^{*}$ - redness to greenness and $b^{*}$ - yellowness to blueness) (CIE, 1976) were determined using MINOLTA Chroma Meter CR-
400 (Minolta Co., Ltd., Osaka, Japan) using D-65 lighting, a $2^{\circ}$ standard observer angle and an 8-mm aperture in the measuring head. The Chroma Meter was calibrated using a Minolta calibration plate (No. 11333090; $Y=92.9, x=0.3159 ; y=$ 0.3322).

\section{Sensory analysis}

Cookie samples were evaluated by a panel of 25 members, students and staff of the Faculty of Technology, University of Novi Sad, $24 \mathrm{~h}$ after baking. In order to evaluate cookie sensory characteristics (appearance, hardness, chewiness, odour, taste and overall acceptability) panellists used 5 - point hedonic scale (1 - dislike very much, 2 - dislike moderately, 3 neither like nor dislike 4 - like moderately, 5 - like very much) (ISO 4121:2002). Cookie samples were served to panellists on white plastic plates labelled with threedigit codes from a random number table. Water and slices of bread were used to clean the mouth between samples.

\section{Statistical analysis}

Statistical analysis was carried out using STATISTICA 12.0 (StatSoft, Inc., Tulsa, OK, USA). All data were presented as mean value with their standard deviation indicated (mean $\pm S D$ ). Variance analysis (ANOVA) was performed, with a confidence interval of 95\% ( $p<0.05)$. Means were compared by Duncan's multiple range test.

\section{RESULTS AND DISCUSSION}

\section{Protein and fibre content}

Control sample had statistically significantly $(p<0.05)$ lower protein and fibre content compared to samples with BSG (Table 1). Protein and total fibre content increased significantly with BSG percentage used for cookies preparation. Cookie sample with $50 \%$ of BSG had $9.69 \%$ protein and even $15.55 \%$ total fibre, which is 1.75 times as much as protein and 5 times as much as fibre compared to sample prepared only with wheat flour. These results confirm that BSG is a potential nutritious food supplement. While the control sample had an equal share of insoluble and soluble fibre, in the cookie 
samples with BSG the amount of insoluble fibre was significantly higher compared to the amount of soluble fibre. Kissell and Prentice (1979) showed that BSG addition at $20 \%$ doubled the crumb protein and lysine content of cookies and increased dietary fibre content by more than fivefold.

\section{Microbiological analysis}

The results of the microbial counts are reported in Table 2. The total number of aerobic mesophilic bacteria was the highest in fresh BSGs $\left(4.0 \times 10^{5} \mathrm{cfu} / \mathrm{g}\right)$. The composition of brewers' spent grain makes it susceptible to microbial attack and chemical deterioration (Robertson et al., 2010). The total number of aerobic mesophilic bacteria increased with increasing amounts of BSG in the cookie samples, and it was highest in sample B50. Yeast and moulds, Escherichia coli and Clostridium spp. were not detected in fresh BSG or in cookie samples. In fresh BSG, Enterobacteriaceae were detected (40 $\mathrm{cfu} / \mathrm{g}$ ), while in all final products, cookie samples, were not.

\section{Cookie colour}

Colour is one of the most important parameters by which consumers evaluate food (Pathare et al., 2013). The colour parameters, lightness ( $L^{*}$ value), redness ( $a^{*}$ value) and yellowness ( $b^{*}$ value) of examined cookies are shown in Table 3. The addition of BSG significantly affected $(P<0.05)$ lightness ( $L^{*}$ value) and redness ( $a^{*}$ value) of samples. Addition of $B S G$ in cookie formulation decreased $L^{*}$ values, i.e. the samples became darker, which is especially pronounced in the sample with $50 \%$ BSG. On the other hand, certain differences in yellowness ( $b^{*}$ value) were not registered between control and samples B25 and B15. The addition of BSG significantly affected cookie yellowness ( $b^{*}$ value) only at the amount of $50 \%$. Ktenioudaki et al., (2013), also concluded that the colour of the crispy slices became visually darker as the level of BSG increased.

Table 1.

Protein and fibre composition (\%) of cookie samples

\begin{tabular}{lcccc}
\hline Sample & Protein & Total fibre & Insoluble fibre & Soluble fibre \\
\hline Control & $5.49 \pm 0.78^{\mathrm{a}}$ & $3.10 \pm 0.14^{\mathrm{a}}$ & $1.56 \pm 0.24^{\mathrm{a}}$ & $1.54 \pm 0.21^{\mathrm{a}}$ \\
B15 & $7.55 \pm 0.41^{\mathrm{b}}$ & $6.80 \pm 0.47^{\mathrm{b}}$ & $4.06 \pm 0.19^{\mathrm{b}}$ & $2.74 \pm 0.35^{\mathrm{b}}$ \\
B25 & $8.28 \pm 0.24^{\mathrm{c}}$ & $8.50 \pm 0.45^{\mathrm{c}}$ & $5.89 \pm 0.65^{\mathrm{c}}$ & $2.61 \pm 0.51^{\mathrm{b}}$ \\
B50 & $9.69 \pm 0.26^{\mathrm{d}}$ & $15.55 \pm 0.78^{\mathrm{d}}$ & $11.47 \pm 0.23^{\mathrm{d}}$ & $4.08 \pm 0.59^{\mathrm{C}}$ \\
\hline
\end{tabular}

Results are given as mean \pm standard deviation $(n=3) ;$ Means with different letters in superscript $(a-d)$ in columns are significantly different $(p<0.05)$

Table 2.

Microbiological profile (cfu/g) of cookies

\begin{tabular}{|c|c|c|c|c|c|c|}
\hline Sample & $\begin{array}{c}\text { Total } \\
\text { aerobic } \\
\text { mesophilic } \\
\text { bacteria }\end{array}$ & $\begin{array}{l}\text { Total yeasts } \\
\text { and moulds }\end{array}$ & $\begin{array}{c}\text { Escherichia } \\
\text { coli }\end{array}$ & $\begin{array}{c}\text { Clostridium } \\
\text { spp. }\end{array}$ & Enterobacteriaceae & $\begin{array}{c}\text { Total aerobic } \\
\text { mesophilic } \\
\text { sporulated bacteria }\end{array}$ \\
\hline$\overline{\mathrm{BSG}}$ & $4.0 \times 10^{5}$ & $<10$ & n.d. & n.d. & 40 & $1.8 \times 10^{2}$ \\
\hline Control & $3.8 \times 10^{3}$ & $<10$ & n.d. & n.d. & $<10$ & $7.5 \times 10^{2}$ \\
\hline B15 & $4.3 \times 10^{3}$ & $<10$ & n.d. & n.d. & $<10$ & $5.5 \times 10^{3}$ \\
\hline B25 & $5.5 \times 10^{3}$ & $<10$ & n.d. & n.d. & $<10$ & $9.0 \times 10^{2}$ \\
\hline $\mathrm{B} 50$ & $7.5 \times 10^{3}$ & $<10$ & n.d. & n.d. & $<10$ & $2.5 \times 10^{3}$ \\
\hline
\end{tabular}

n.d. $=$ not detected

Table 3.

CIE L*, $a^{*}, b^{*}$ values of cookie color

\begin{tabular}{lccc}
\hline Sample & $\mathbf{L}^{*}$ & $\mathbf{a}^{*}$ & $\mathbf{b}^{\mathbf{}}$ \\
\hline Control & $79.27 \pm 0.56^{\mathrm{d}}$ & $0.09 \pm 0.16^{\mathrm{a}}$ & $22.31 \pm 0.32^{\mathrm{b}}$ \\
B15 & $73.17 \pm 0.78^{\mathrm{c}}$ & $1.88 \pm 0.21^{\mathrm{b}}$ & $22.33 \pm 0,21^{\mathrm{b}}$ \\
B25 & $70.11 \pm 0.39^{\mathrm{b}}$ & $3.35 \pm 0.19^{\mathrm{c}}$ & $22.05 \pm 0,36^{\mathrm{b}}$ \\
B50 & $58.23 \pm 0.48^{\mathrm{a}}$ & $5.62 \pm 0.14^{\mathrm{d}}$ & $21.25 \pm 0.21^{\mathrm{a}}$
\end{tabular}

Results are given as mean \pm standard deviation $(n=3)$; Means with different letters in superscript $(a-d)$ in columns are significantly different $(p<0.05)$ 


\section{Sensory analysis}

The panellists have given higher scores for all evaluated attributes to the control cookie sample (Figure 1.). Kim et al., (2001) also reported that the overall sensory score decreased when biscuits contained more than 15\% BSG. Kissell and Prentice (1979) found that BSG addition was limited to $15 \%$ before an unacceptable flavour developed in cookies. Prentice and D'Appolonia (1977) reported that breads with 5 and 10\% BSG had good sensory properties and were accepted by consumers. In the cookie samples B15, B25 and B50, parts of BSG and cracks were visible on the cookie surface. Addition of BSG generally influenced the formation of a darker co- okies colour as a result of higher protein content in BSG which caused intensive Maillard reactions (Rufián-Henares et al., 2009). The negative impact BSG addition had on the hardness and chewiness. BSG has high amount of proteins and fibre which absorb water causing cookie hardening. Because they were not milled, addition of BSG in cookies leads to the appearance of large particles in the mouth. The samples with highest BSG level (B50) had the higher amount of small, hard particles that lag between teeth during chewing. This sample had the lowest scores for chewiness. For odour, taste and overall acceptability the highest score was given to sample B25 and the lowest score to sample B50.

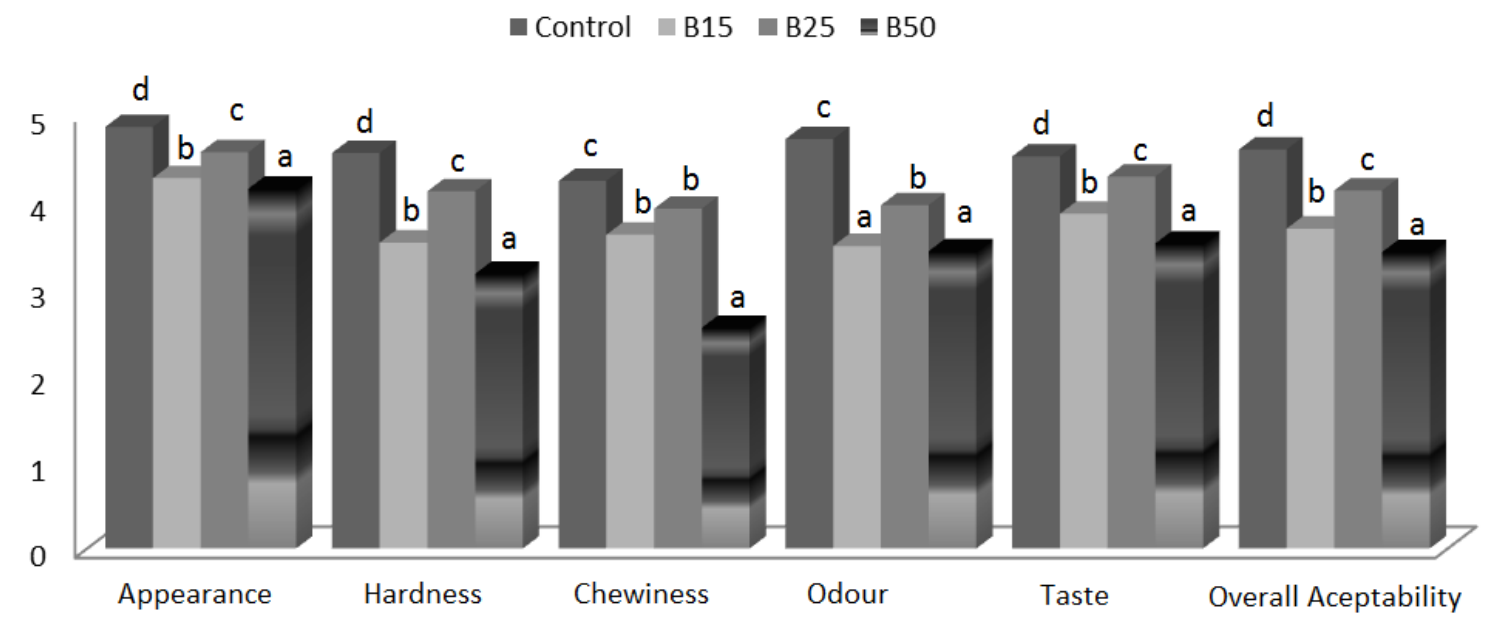

Figure 1. Sensory characteristics of control cookie and cookies with BSG. The means followed by different letters are indicated as significantly different $(p<0.05)$

\section{CONCLUSION}

The results confirm that BSG is a potential nutritious food supplement. Cookie sample with $50 \%$ of BSG had 1.75 times as much as protein and 5 times as much as fibre compared to sample prepared only with wheat flour. On the other hand, although fresh BSG possessed Enterobacteriaceae, they were not detected in cookie samples, as well as E. coli, Clostridium spp., yeasts and moulds. Addition of BSG in cookies formulation decreased $L^{*}$ and increased $a^{*}$ values of cookie colour. The results of sensory analysis showed that cookie samples were well evaluated for appearance by panellists. Addition of BSG had negative impact on the hardness and chewiness of cookies. The highest values for overall acceptability, odour and taste had sample B25. It can be concluded that BSG used fresh, no-milled and without thermal treatment, immediately after beer processing, do not impair microbiological stability and sensory characteristics of cookies, while increase its nutritional value.

The maximum amount of fresh BSG that would be included in cookie preparation should not exceed $25 \%$, since larger amount caused significantly lower scores for cookies sensory characteristics. 


\section{ACKNOWLEDGMENT}

The authors highly appreciate financial support of the Provincial Secretariat for High Education and Scientific Research of the Government of Autonomous Province of Vojvodina, Republic of Serbia, project 114-451-2085/2016: Valorization of byproducts of the food industry through the development of nutritionally enriched cookies and cracker.

\section{REFERENCES}

1. AOAC (2000). Official Methods of Analysis of AOAC International, $17^{\text {th }}$ Ed, Gaithersburg, MD, USA.

2. AOAC (1997). Official methods Methods of analysis Analysis of AOAC International, $16^{\text {th }}$ Ed. Washington, DC., Official Method 985.29.

3. Arshad, M.U., Anjum, F.M., Zahoor, T. (2007). Nutritional assessment of cookies supplemented with defatted wheat germ. Food Chemistry, 102, 123-128.

4. International Commission on Illumination (1976). Official recommendations on uniform colour space, colour difference equations and metric colour terms. In Colorimetry, 2nd Ed. pp. 9-12. Publication CIENo.15.2. Commission International de l'Eclairage, Paris, France.

5. ISO 4121:2002 (2002). Sensory analysis Methodology - Evaluation of food product by methods of using scales, International Organization for Standardization.

6. El-Shafey, E.I., Gameiro, M.L.F., Correia, P.F.M., De Carvalho, J.M.R. (2004). Dewatering of brewer's spent grain using a membrane filter press: a pilot plant study. Separation Science and Technology, 39 (14), 3237-3261.

7. Finley, J.W., Hanamoto, M.M. (1980). Milling and baking properties of dried brewer's spent grains. Cereal Chemistry, 57, 166-168.

8. Kawka, A., Gorecka, D., Gąsiorowski, H. (1999). The effects of commercial barley flakes on dough characteristics and bread composition. Electronic Journal of Polish Agricultural Universities, 2 (2), 1-8.

9. Kissell, L.T., Prentice, N. (1979). Protein and fibre enrichment of cookie flour with brewer's spent grain. Cereal Chemistry, 56 (4), 261-266.

10. Kim, H.Y.L., Yeom, H.W., Lim, H.S., \& Lim, S.T. (2001). Replacement of shortening in yellow layer cakes by corn dextrins. Cereal Chemistry, 78 (3), 267-271.

11. Kitrytè, V., Šaduikis, A., Venskutonis, P.R. (2015). Assessment of antioxidant capacity of brewer's spent grain and its supercritical carbon dioxide extract as sources of valuable dietary ingredients. Journal of Food Engineering, 167, 18-24.

12. Ktenioudaki, A., Chaurin, V., Reis, S.F., Gallagher, E. (2012). Brewer's spent grain as a functional ingredient for breadsticks. Interna- tional Journal of Food Science \& Technology, 47 (8), 1765-1771.

13. Ktenioudaki, A., O'Shea, N., Gallagher, E. (2013a). Rheological properties of wheat dough supplemented with functional by-products of food processing: Brewer's spent grain and apple pomace. Journal of Food Engineering, 116 (2), 362-368.

14. Ktenioudaki, A., Crofton, E., Scannell, A.G., Hannon, J.A., Kilcawley, K.N., Gallagher, E. (2013b). Sensory properties and aromatic composition of baked snacks containing brewer's spent grain. Journal of Cereal Science, 57 (3), 384-390.

15. Laufenberg, G., Kunz, B., Nystroem, M. (2003). Transformation of vegetable waste into value added products: $(A)$ the upgrading concept;(B) practical implementations. Bioresource Technology, 87 (2), 167-198.

16. Lorens, K., Dilsaver, W., Wolt, M. (1979). Faba bean flour and protein concentrate in baked goods and in pasta products. Bakers Digest, $53,39-42$.

17. Manley, D. (Ed.). (2011). Manley's Technology of Biscuits, Crackers and Cookies. Woodhead Publishing Limited, Cambridge, England.

18. McCarthy, A.L., O'Callaghan, Y.C., Connolly, A., Piggott, C.O., FitzGerald, R.J., O'Brien, N.M. (2012). Phenolic extracts of brewers' spent grain (BSG) as functional ingredientsAssessment of their DNA protective effect against oxidant-induced DNA single strand breaks in U937 cells. Food Chemistry, 134 (2), 641-646.

19. Meneses, N.G., Martins, S., Teixeira, J.A., Mussatto, S.I. (2013). Influence of extraction solvents on the recovery of antioxidant phenolic compounds from brewer's spent grains. Separation and Purification Technology, 108, 152158.

20. Mussatto, S.I., Dragone, G., Roberto, I.C. (2006). Brewers' spent grain: generation, characteristics and potential applications. Journal of Cereal Science, 43 (1), 1-14.

21. Pathare, P.B., Opara, U.L., Al-Said, F.A.J. (2013). Colour measurement and analysis in fresh and processed foods: a review. Food and Bioprocess Technology, 6 (1), 36-60.

22. Petrović, J., Fišteš, A., Rakić, D., Pajin, B., Lončarević, I., Šubarić, D. (2015). Effect of defatted wheat germ content and its particle size on the rheological and textural properties of the cookie dough. Journal of Texture Studies, 46 (5), 374-384.

23. Prentice, N., D'Appolonia, B.L. (1977). Highfiber bread containing brewer's spent grain. Cereal Chemistry, 54, 1084-1095.

24. Prentice, N., Kissell, L.T., Lindsay, R.C., Yamazaki, W.T. (1978). High-fiber cookies containing brewers' spent grain. Cereal Chemistry, 22, 470 $-465$.

25. Robertson, J.A., l'Anson, K.J., Brocklehurst, T.F., Faulds, C.B., \& Waldron, K.W. (2010). Effect of storage conditions on the microbial ecology and biochemical stability of cell wall components in Brewers' spent grain. Journal of 
Agricultural and Food Chemistry, 58 (12), 72667272.

26. Rodriguez, R., Jimenez, A., Fernández-Bolaños, J., Guillén, R., Heredia, A. (2006). Dietary fiber from vegetable products as source of functional ingredients. Trends in Food Science \& Technology, 17 (1), 3-15.

27. Rufián-Henares, J.A., Delgado-Andrade, C., Morales, F.J. (2009). Assessing the Maillard reaction development during the toasting process of common flours employed by the cereal products industry. Food Chemistry, 114 (1), 9399.

28. Santos, M., Jiménez, J.J., Bartolomé, B., Gómez-Cordovés, C., Del Nozal, M.J. (2003). Variability of brewer's spent grain within a brewery. Food Chemistry, 80 (1), 17-21.

29. Steinmacher, N.C., Honna, F.A., Gasparetto, A.V., Anibal, D., Grossmann, M.V. (2012). Bioconversion of brewer's spent grains by reactive extrusion and their application in breadmaking. LWT-Food Science and Technology, 46 (2), 542-547.
30. Stojceska, V. (2011). Dietary fibre from brewer's spent grain as a functional ingredient in bread making technology. In Flour and Breads and their Fortification in Health and Disease Prevention, Eds. V. Preedy R. R. Watson V. Patel, Academic Press, Cambridge, Massachusetts, pp. 171-179.

31. Stojceska, V., Ainsworth, P. (2008). The effect of different enzymes on the quality of high-fibre enriched brewer's spent grain breads. Food Chemistry, 110 (4), 865-872.

32. Stojceska, V., Ainsworth, P., Plunkett, A., Ibanog lu, S. (2008). The recycling of brewer's processing by-product into ready-to-eat snacks using extrusion technology. Journal of Cereal Science, 47 (3), 469-479.

33. Sudha, M.L., Vetrimani, R., Leelavathi, K. (2007). Influence of fiber from different cereals on the rheological characteristics of wheat flour dough and on biscuit quality. Food Chemistry, 100 (4), 1365-1370.

\title{
КВАЛИТЕТНЕ КАРАКТЕРИСТИКЕ ЧАЈНОГ ПЕЦИВА ОБОГАЋЕНОГ СВЕЖИМ ТРОПОМ ПИВА
}

\author{
Јована С. Петровић,"1, Биљана С. Пајин, Сунчица Д. Коцић Танацков, Јелена Д. Пејин, \\ Александар 3. Фиштеш, Немања Ђ. Бојанић, Ивана С. Лончаревић \\ Универзитет у Новом Саду, Технолошки факултет Нови Сад, \\ 21000 Нови Сад, Булевар цара Лазара бр. 1, Србија
}

Сажетак: Пивски троп је нуспроизвод који настаје током процеса производње пива. Богат је извор влакана и протеина, са великим потенцијалом за повећање нутритивне вредности прехрамбених производа. У овом истраживању различите количине свежег (без сушења и млевења) пивског тропа су додате у тесто за производњу чајног пецива, на бази замене пшеничног брашна тропом $(15,25$ и $50 \%)$ како би се проценио утицај на садржај влакана и протеина, инструменталне параметре боје, микробиолошку стабилност и сензорске карактеристике готовог производа. Садржај протеина повећао се од 7,55\% до 9,69\%, а садржај влакана од 6,8 до $15,55 \%$, након додатка тропа пива. Додатак тропа пива изазвао је смањење $L^{*}$ и $b^{*}$ вредности боје чајног пецива, док су се $a^{*}$ вредности повећале. Enterobacteriaceae, $E$. coli, Clostridium spp., квасци и плесни нису детектовани у узорцима чајног пецива са тропом пива, док су Enterobacteriaceae детектоване (40 cfu/g) у свежем тропу пива. Додатак $25 \%$ тропа пива резултирао је најбољим сензорским карактеристикама чајног пецива у погледу изгледа површине, тврдоће, зрнавости и укуса. Резултати су показали да свеж троп пива има потенцијал да повећа нутритивну вредност чајног пецива без негативног утицаја на њихове сензорске карактеристике и микробиолошку стабилност.

Кључне речи: чајно пециво, пивски троп, боја, сензорска својства, влакна, микробиолошка стабилност

Received: 27 January 2017

Accepted: 30 March 2017 